\title{
Nutrient Composition and Calorific Value of Some Seaweeds from Bet Dwarka, West Coast of Gujarat, India
}

\author{
Nirmal Kumar J.I. ${ }^{1 *}$, R.N. Kumar ${ }^{2}$, K. Patel $^{1}$, S. Viyol ${ }^{1}$ and R. Bhoi ${ }^{1}$ \\ ${ }^{1}$ P.G. Department of Environmental Science and Technology, Institute of Science and Technology for Advanced \\ Studies and Research (ISTAR), Vallabh Vidyanagar-388120, Gujarat, India. \\ ${ }^{2}$ Department of Bioscience and Environmental Science, N.V. Patel college of Pure and Applied Sciences, \\ Vallabh Vidyanagar - 388 120, Gujarat, India. \\ "E-mail: istares2005@yahoo.com
}

Received: 01.01.2009, Accepted: 29.05.2009

\begin{abstract}
Seaweeds are used many folds for animal and human food, soil manure, salt extractions (soda, iodine etc.) and colloid production (agar-agar, al ginate, carrageenan, furcellaran etc.), cosmetics and pharmaceutics. These represent important economical resources in world wide, where they are not only largely harvested but also intensively and largely employed in the human nutrition. Mineral composition of seaweeds was found relatively higher as compared to the land vegetables. Keeping the significance in mind, in current work nine seaweeds such as Chaetomorpha spp., Cladophora facicaularis, Ulva lactuca, Caulerepa racemosa, Caulerepa sertularioides, Valoniopsis pachynema, Sargassum ilicifolium, Sargassum polycustum and Porphyra vietnamensis growing along the Bet Dwarka, West Coast of Gujarat, India were collected and analyzed for nutrient / mineral composition like $\mathrm{Mg}, \mathrm{K}, \mathrm{Na}, \mathrm{Ca}, \mathrm{S}, \mathrm{N}, \mathrm{Cl}$ and $\mathrm{P}$, ash content and calorific value. The nutrient concentration ranges found for each sample, were as follows: $\mathrm{Mg}, 70.4-248.1 ; \mathrm{K}, 16.6-128.04 ; \mathrm{Na}, 78.7-$ 129.07; Ca, 121-476.67; S, 101.11-214.99; N, 34.31-56.34; Cl, 26.12-235.66; and P, 0.781.53 expressed in $\mathrm{g} / 100 \mathrm{~g}$ dry weight. Calorific content and ash content, ranged between 11.3-22.6 MJ/Kg and 23.0-41.9 g/100 g dry weight, respectively. Calorific content was negatively correlated with ash content and nutrient composition, but ash content was found to be positive correlation with mineral composition of selected sea weeds.
\end{abstract}

Key words: Seaweeds, Ulva lactuca Nutritional composition, Calorific content, Ash content

\section{Introduction}

Seaweeds are macroscopic algae found in relatively shallow coastal waters. They grow in the intertidal, shallow and deep sea areas up to 180 meter depth and also in estuaries and back waters on the solid substrate such as rocks, dead corals, pebbles, shells and other plant materials (Anantharaman, 2002). They are belonging to three dominant

groups, Chlorophyceae (green algae), Phaeophyceae (brown algae) and Rhodophyceae (red algae). Seaweeds are known to be important source of phytochemicals like agar-agar, carrageenan and alginate, which are extensively used in various industries such as food, confectionary, textiles, pharmaceuticals, 
dairy and paper industries mostly as gelling, stabilizing and thickening agents. They are also used for animal and human consumption, as soil manure, salt extractions, in several countries. Some seaweed are used or indicated as biomonitors to study the environmental contamination (Caliceti et al., 2002).

There are several seaweeds species found growing naturally on reefs of bet Dwarka area, Okha, in the Gulf of Kutch, West coast of India. The stranded seaweeds constituted a total of 62 species of this, Rhodophyta ranked high with 26 species followed by Chlorophyta with 22 species and Phaeophyta with 14 species. The major species include Sargassum, Ulva, Caulerpa, Porphyra, Cladophora, Padina etc. The mineral compositions of the seaweeds are much more concerned because of their role as a food. Reports on certain edible seaweeds showed that they contain significant amount of proteins, vitamins, and minerals essential for human nutrition (Oohusa, 1993). The nutrient and mineral composition of some species of seaweeds was investigated by many workers (Esteves et al., 2005; Krishnaiah et al., 2008). The nutrient composition of seaweed varies and is affected by species, geographic area and the season of the year and temperature of the water (Jensen, 1993).

Further interest in the calorific content of seaweeds is due to their increasing utilization in aquaculture (Vadas et al., 2000). Although the chemical composition of seaweed is routinely examined, quantitative measures of calorific content using bomb calorimeters are recorded less often (Gomez and Westermeier, 1995). In this paper we discuss the nutrient composition, calorific value and ash content of some nat urally occurring seaweeds on the reefs of islands of bet Dwarka area, Okha, in the Gulf of Kutch, West coast, India.

\section{Study area}

Port Okha (Lat. 22 28 'N and Long. $69^{\circ} 05^{\prime} \mathrm{E}$ ), situated at the mouth of "Gulf of Kutch" on the north-westernmost part of Sa urashtra of Gujarat (Figure 1). The town is famous for its Lord Krishna Temple "Bet Dwaraka" residence of Lord Krishna. Present study was carried out at the coastal reefs present on the "Bet Dwaraka" Island. The reefs provide shallow and favorable conditions for the abundant seaweed growth in the area.

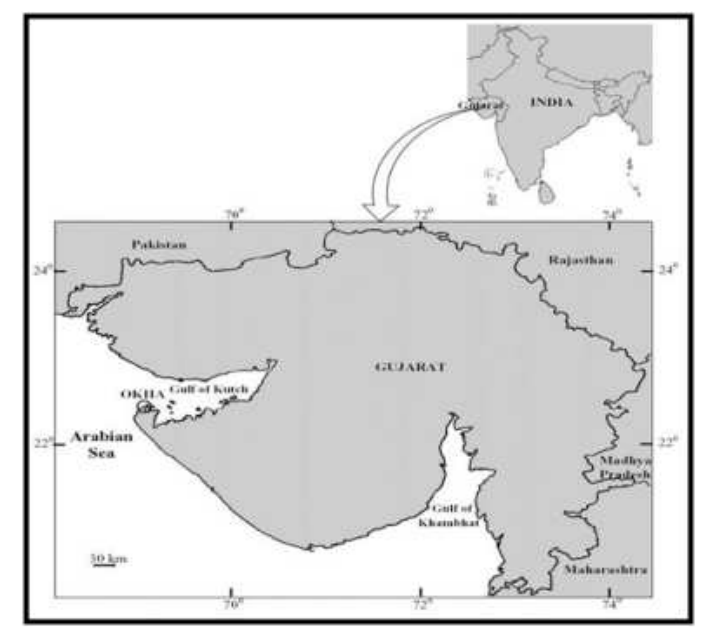

Figure 1. Map of India showing the study site of Bet Dwarka, Okha

\section{Mate rials and methods}


Nine seaweed samples with relevant biomass (visually estimated) were collected during ebb tide from upper littoral rocks of above mentioned location in the third week of January 2009. The samples were immediately washed with surrounded sea water to remove the adhered sand. They were conditioned in plastic bags and kept in ice box, until carried to the laboratory. Samples were brought to the laboratory and washed thoroughly with distilled water to remove attached epiphytes and adhered dirt particles if any. All the samples were oven dried at $80^{\circ} \mathrm{C}$ for two days to constant weight and milled to particle size less than 2 $\mathrm{mm}$ and kept in air tight plastic bottles at room temperature. All determinations were performed at least in triplicate and data reported on a dry matter basis as mean values \pm st andard error.

\section{Nutrient analysis}

Magnesium ( $\mathrm{Mg}$ ) and Calcium ( $\mathrm{Ca}$ ) were determined by EDT A titration method, after digestion with acid (Maiti, 2003), whereas Potassium (K) and Sodium (Na) were measured by flame photometer. Chloride (Cl) and Sulfur were determined by silver nitrate and barium chloride methods, respectively (APHA, 1998; Maiti, 2003). The total nitrogen $(\mathrm{N})$ was determined by cmicro- Kjeldahl technique; after digestion with mixture $\left(\mathrm{CuSO}_{4}+\mathrm{K}_{2} \mathrm{SO}_{4}+\mathrm{H}_{2} \mathrm{SO}_{4}\right)$ using Gerhardt (Vap 10) distillation assembly, Germany (APHA, 2003; Maiti, 2003). Total phosphorous was quantified after acid digestion followed by stannous chloride colorimetric method (Narwal, 2007).

\section{Ash content}

The ash content of sea weeds was determined according to T APPI standard T $211 \mathrm{om}-85.500 \mathrm{mg}$ pellets of each dried seaweed samples was weighed, combusted in a muffle furnace at $550^{\circ} \mathrm{C}$ for $4 \mathrm{~h}$, and then re-weighed. The ash content (\%) dry weight was calculated as:

Ash content $=\mathrm{m}_{\text {ash }} \times 100 / \mathrm{m}_{\text {oven dry }}$

\section{Calorific value}

The calorific content of dried sea weed samples was measured using a Rajdhani ${ }^{\circledR}$ bomb calorimeter. Small pellets of dried sample $(500 \mathrm{mg})$ were placed in the bomb chamber, pressurized to $425 \mathrm{psi}$ with pure oxygen, combusted and the amount of different of heat liberated recorded. The bomb-calorimeter was calibrated against benzoic acid standards before the analy sis of samples.

\section{Statistical analysis}

Student "t" test was used to test significant differences between Seaweeds and Nutrients.

\section{Resul ts and discussion}

Among nine seaweeds, six species are belonging to Chlorophyta (Green) membersChaetomorpha spp., Cladophora facicaularis, Ulva lactuca, Caulerepa racemosa, Caulerepa sertularioides and Valoniopsis pachynema while two species belonging to Pheophyta (Brown)Sargassum ilicifolium and Sargassum polycustum and only one belonging to Rhodophyta (Red)- Porphyra vietnamensis. 
The seaweeds contained high quantity of the total macro nutrients ranged from $501.6 \%$ in Cladophora facicaularis to $943.74 \%$ in Valoniopsis pachynema (Figure $2)$. The distinct variation observed in the mineral composition of different seaweeds in the present study as shown in Figure 2 to 5. Magnesium content varied from $70.4 \pm 1.24 \%$ in Sargassum polycustum and $248.1 \pm 1.3 \%$ in Caulerepa sertularioides (Figure 3) which has key role as a cofactors of many enzyme-linked biochemical reaction in different physiological processes; ATP dependant metabolic reactions; essential for brain and liver function; calms nerves; promotes cell growth; increases tissue elasticity; neuromuscular functions (McDermid and Stuercke, 2003). Potassium content was elevated values in the range from $16.59 \pm 0.8 \%$ in Sargassum polycustum to $128.04 \pm 1.08 \%$ in Caulerepa racemosa (Figure 3) as it is an important nutrient for proper membrane function, nerve impulses, and muscle contractions; major cation in cytoplasm; a primary electrolyte and alkalizer; attracts oxygen to tissues; helps eliminate toxins from the body (Ruperez, 2002). Sodium concentration varied from $78.74 \pm 1.42 \%$ in Sargassum polycustum and $129.1 \pm 2.71 \%$ in Porphyra vietnamensis (Figure 3) which is stored in stomach walls, joints, and gallbladder; helps prevent blood clotting; important for membrane function, nerve impulses, and muscle contractions; major cation in body fluids; contributes to the alkalinity of the lymph and blood; works with the bicarbonate buffer system in the digestive tract to prevent hydrochloric acid from burning stomach walls; helps retain calcium and cholesterol liquid in the body; helps with excretion of carbon dioxide $\left(\mathrm{CO}_{2}\right)$ (Subba Rao et al., 2007).

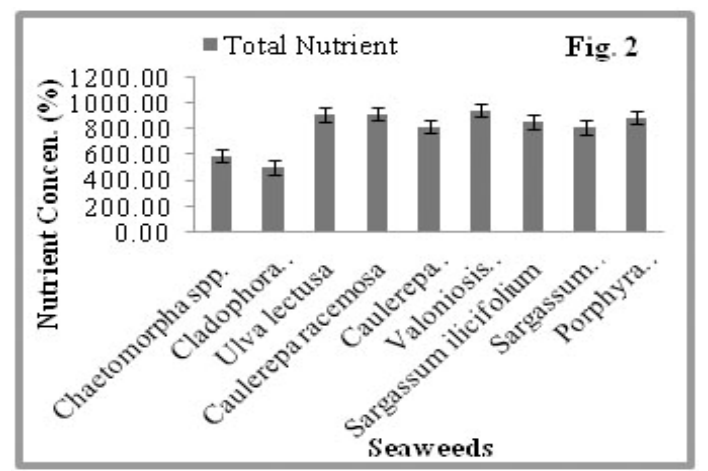

Figure 2. Total nutrient content (\%) of different seaweeds.

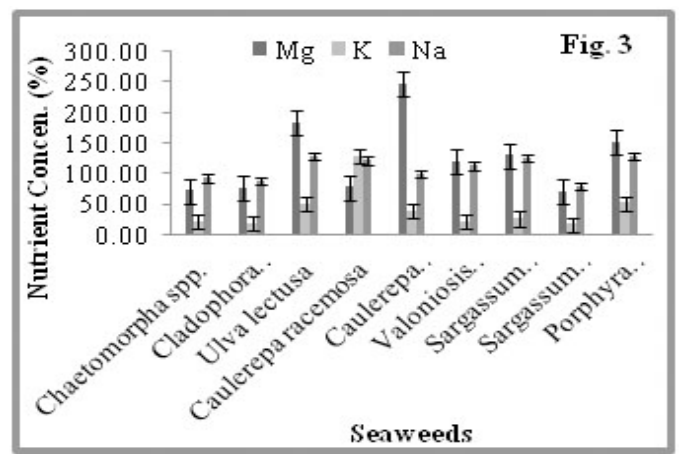

Figure 3. $\mathrm{Mg}, \mathrm{K}, \mathrm{Na}$ content (\%) of different seaweeds.

Calcium content varied in nine seaweeds was found to be highest $(476.67 \pm 6.2 \%)$ in Valoniopsis pachynema and lowest $(121 \pm 2 \%)$ in Cladophora facicaularis (Figure 4) which is required for the formation of bones and teeth structure, mineral for clotting of blood, and also controls the functions of nerves and 
muscles. It acts as a cofactor for extra cellular enzyme and proteins. Sulfur content diverse in different seaweed species like Chaetomorpha spp., Cladophora facicaularis, Ulva lactuca, Caulerepa racemosa, Caulerepa sertularioides, Valoniopsis pachynema, Sargassum ilicifolium, Sargassum polycustum and Porphyra vietnamensis contained $142 \pm 1.88$, $123.4 \pm 0.97, \quad 200.73 \pm 2.13, \quad 158.55 \pm 2.3$, $209.40 \pm 1.73, \quad 104.02 \pm 0.69, \quad 214.99 \pm 2.15$, $126.14 \pm 1.72,101.11 \pm 1.18 \%$ in dry weight respectively (Figure 4) which also found in many amino acids as well as thiamine and biotin; necessary for developmental and neurological processes and for synthesis of collagen; detoxifies; increases blood circulation; reduces muscle cramping and back pain; removes inflammation; assists in the healing of muscles; helps the liver produce choline; an important nutrient in nerves and the myelin sheath; stimulates flow of bile; regulates heart and brain function; promotes healthy skin, nails, and hair; helps lubricate joints (Ito and Hori, 1989).

Nitrogen is found in proteins, nucleic acids, and other organic compounds (Fleurence, 1999).which is ranged from $34.31 \pm 0.37 \%$ in Caulerepa racemosa to $56.34 \pm 0.54 \%$ in Chaetomorpha spp (Figure 5). Chloride content is an important for membrane function and water absorption; chloride is the major anion in body fluids and part of hydrochloric acid $(\mathrm{HCl})$ in gastric juices. It also helps in maintaining of acid-base balance (Darcy-Vrillon, 1993) which ranged from $26.12 \pm 0.99 \%$ in
Cladophora facicaularis to $235.66 \pm 1.45 \%$ in Caulerepa racemosa (Figure 5).

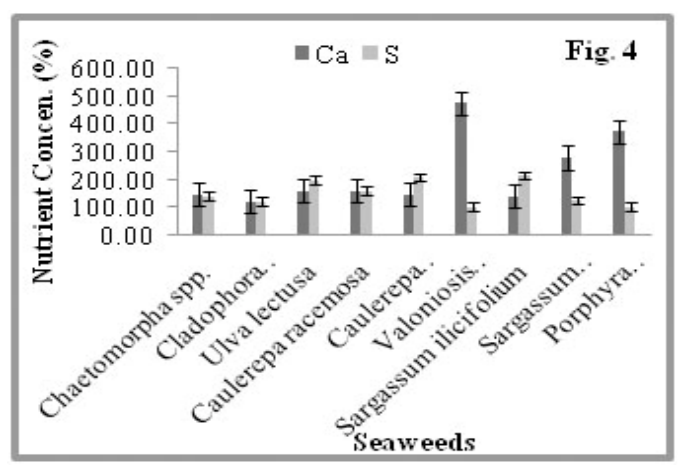

Figure 4. Ca and S content (\%) of different seaweeds.

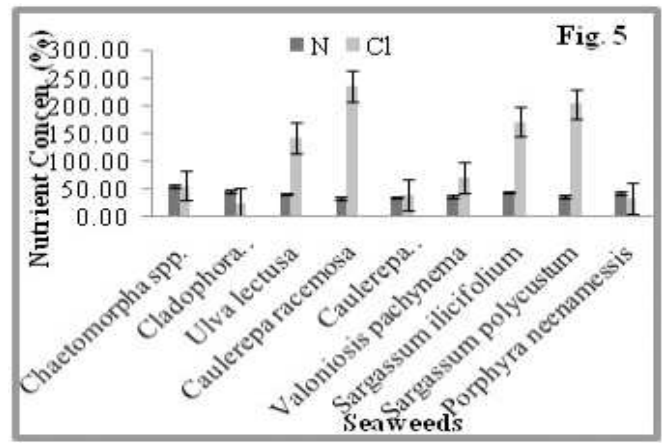

Figure 5. $\mathrm{N}$ and $\mathrm{Cl}$ content (\%) of different seaweeds.

Phosphorus found in the nucleus of every cell in the body (including white blood cells), nucleic acids, high-energy compounds, and phosphate buffer system; a major component of outer bone; combines with such nutrients as iron, potassium, sodium, magnesium and calcium; necessary for the reproductive system and sexual function; necessary for muscle tissue and growth; an essential nutrient for the nerves (Ruperez, 2002) which also present in 
seaweeds in very minute quant ity than other minerals. It varied from $0.777 \pm 0.026 \%$ in Sargassum ilicifolium to $1.534 \pm 0.014 \%$ Caulerepa racemosa (Figure 6). Among all the 8 macro nutrient analyzed $\mathrm{Ca}$ content was registered to be highest $(476.67 \pm 6.2 \%)$ in Valoniopsis pachynema (Figure 4) while $\mathrm{P}$ concentration was appeared to be the lowest $(0.777 \pm 0.026 \%)$ in Sargassum ilicifolium (Figure 6) Significant differences between all seaweeds and nutrients is $* * * \mathrm{P}<=0.001$.

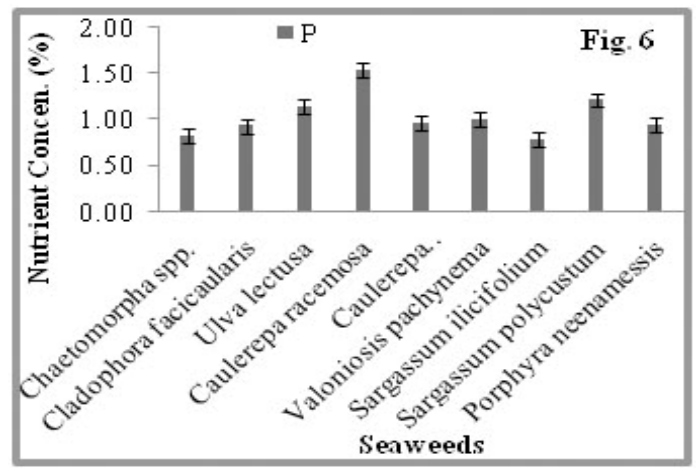

Figure 6. P content (\%) ofdifferent seaweeds.

Mean total nutrient concentration in different species as follows: Cladophora facicaularis, Chaetomorpha spp., Caulerepa sertularioides, Sargassum polycustum, Sargassum ilicifolium, Porphyra vietnamensis, Ulva lactuca, Caulerepa racemosa and Valoniopsis pachynema which contained $62.7<73.74<101.52<101.95<106.92<110.66$ $<113.72<114.94<117.97 \%$ dry weight respectively. Mean nutrient concentration of each metal is as follows: $\mathrm{P}, \mathrm{K}, \mathrm{N}, \mathrm{Na}, \mathrm{Cl}$, $\mathrm{Mg}, \mathrm{S}$ and $\mathrm{Ca}$ contained $1.03<41.2<41.94<$ $108.56<108.92<125.44<153.37<223.19 \%$ dry weight.

The seaweed nutrient variation might be due to, oceanic residence time, seasonal, environmental, physiological factors, type of processing and method of mineralization and seaweed species (Honya and Kinoshita, 1993). Besides, the seasonal parameter such as time, intensity of light, salinity and water temperature effect the growth rate of seaweeds. Light is one of the main abiotic factors that regulate seaweed growth and distribution in the marine habitat Hanelt et al. (1997). The optimum salinity required for some seaweed about 28-34 parts per thousand (ppt) and in the water temperature range $25-30^{\circ} \mathrm{C}$.

Calorific content of dried seaweeds ranged from $11.3 \pm 0.08 \mathrm{MJ} / \mathrm{Kg}$ dwt in Chaetomorpha spp. to $22.6 \pm 0.14 \mathrm{MJ} / \mathrm{Kg}$ dwt in Sargassum polycustum (Table 1) $(* * * \mathrm{P}<=0.001)$. Paine and Vadas (1969) carried out a survey of the calorific content in 75 temperate seaweed species from North America and found large variations in calorific content, both interspecifically and spatially. In general however, present study reveled that calorific content registered highest in Pheophyta, followed by Rhodophyta and lowest in Chlorophyta (Table 1). The greatest contributor to calorific content of a seaweed is the portion that is inorganic (i.e. ash content) which can explain the observed variation in calorific 
N. Kumar J.I., R.N. Kumar, K. Patel, S. Viryol and R. Bhoi / Our Nature (2009) 7: 18-25

Table 1. Calorific value and ash content of Okha seaweeds.

\begin{tabular}{lllcc}
\hline Genus & Class & Species & Calonific Content & Ash Content \\
\hline Chaetomorpha & Green & Spp. & $11.3 \pm 0.08$ & $41.6 \pm 0.14$ \\
Cladophora & Green & facicaularis & $12.1 \pm 0.11$ & $40.4 \pm 0.21$ \\
Ulva & Green & Lactuca & $14.1 \pm 0.12$ & $34.8 \pm 0.20$ \\
Caulerepa & Green & Racemosa & $13.3 \pm 0.09$ & $36.4 \pm 0.14$ \\
Caulerepa & Green & sertularioides & $13.7 \pm 0.11$ & $34.2 \pm 0.18$ \\
Valoniopsis & Green & pachynema & $12.9 \pm 0.12$ & $37.0 \pm 0.17$ \\
Sargassum & Brown & Ilicifolium & $21.8 \pm 0.12$ & $24.8 \pm 0.17$ \\
Sargassum & Brown & polycustum & $22.6 \pm 0.14$ & $23.0 \pm 0.14$ \\
Porphyra & Red & vietnamensis & $16.3 \pm 0.18$ & $30.8 \pm 0.20$ \\
\hline
\end{tabular}

Mean values of triplicate determination \pm standard error.

content between species on a dry weight basis. Calorific content is negatively correlated to ash content with high ash content species such as Chaetomorpha spp, Cladophora facicaularis, Ulva lactuca, Caulerepa racemosa, Caulerepa sertularioides and Valoniopsis pachynema having lowest calorific value (Norziah and Ching, 2000). Ash content ranged from $23.0 \pm 0.14 \%$ in Sargassum polycustum to $41.6 \pm 0.14 \%$ in Chaetomorpha spp (Table 1) $(* * * \mathrm{P}<=0.001)$. Although ash content varied within each group, average ash content was lowest in Pheophyta than the Rhodophyta and Chlorophyta see Table 1 . (Miles and Stephen, 2001).

\section{Conclusion}

The seaweeds or sea grasses form one of the vital components of all most all ecosystems. The seaweeds from the okha coast, Gujarat were analyzed for macro nutrients, calorific content, and ash content. Some of the macro nutrients were in moderate level in Cladophora facicaularis, Chaetomorpha spp., Caulerepa sertularioides, Sargassum polycustum, Sargassum ilicifolium whereas others were at high level in Porphyra vietnamensis, Ulva lactuca, Caulerepa racemosa and Valoniopsis pachynema. The nutritional composition of the macro algae from Okha, Gujarat points out to the fact that they may be used as potential food supplements as a spice to improve the nutritive value in the diet.

\section{Refe rences}

American Public Health Association 1998. Standard methods for the examination of water and sewage. $20^{\text {th }}$ ed. Washington DC.

Anantharaman, P. 2002. Manual on identification of seaweeds. All India coordinated project on "Survey and inventorization of coastal and marine Biodiversity" (East coast). 102p.

Caliceti, M., E. Argese, A. Sfriso and B. Pavoni 2002. Heavy metal contamination in the seaweeds of Venice lagoon. Chemosphere. 47:443-454.

Darcy-Vrillon, B. 1993. Nutritional aspects of the 
N. Kumar J.I., R.N. Kumar, K. Patel, S. Viryol and R. Bhoi / Our Nature (2009) 7: 18-25

developing use of marine macro algae for the human food industry. International Journal of Food Science and Nutrition 44: S23-S35.

Esteves, B.S., A. Taouil and M.S. Suzuki 2005. Nutrient composition of macroalgae and macrophytes of the Açu lagoon, Rio de Janeiro State, Brazil. Acta Limnol. Bras. 17(3): 233-244.

Fleurence, J. 1999. Seaweed proteins: biochemical, nutritional aspects and protein uses. Trends Food Sci. Technol.10:25-28.

Gomez, I. and R. Westermeier 1995. Energy contents and organic constituents in Antarctic and south Chilean marine brown algae. Polar Biology 15: 597-602.

Hanelt, D., C. Wiencke, U. Karsten and W. Nultsch 1997. Photo inhibition and recovery after high light stress in different developmental and life history stages of Laminaria sachharina (Phaeophyta). J. Phycol. 33: 387-395.

Honya, M. and T. Kinoshita 1993. Monthly determination of alginates, N/G ratio mannitol and minerals in cultivated Laminaria japonica. Nippon Suisan Gakkalshi. 59: 295-299.

Ito, K. and K. Hori 1989. Seaweed: Chemical composition and potential foods uses. Food Rev. Int. 5: 101-104.

Jensen, A. 1993. Present and future Needs for Alga and Algal products. Hydrobiology 260/261:15-21.

Krishnaiah, D., R. Sarbatly, D.M.R. Prasad and A. Bono 2008. Mineral Content of some seaweeds from Sabah's China Sea. Asian Journal of Scientific Research 1(2): 166-170.

Maiti, S.K. 2003. Handbook of Methods in Environmental Studies Vol.2: Air, Noise, Soil, and
Overburden Analysis. ADB Publisher, Jaipur, India, ISBN: 81-85771-58-8.

McDermid, K.J. and B. Stuercke 2003. Nutritional composition of edible Hawaiian seaweeds. Journal of Applied Phycology 15:513-524.

Miles, D.L. and R.W. Stephen 2001. Calorific content of New Zealand marine macrophytes. New Zealand Journal of Marine and Freshwater Research 35: 335-341.

Narwal, S.S. 2007. Research Methods in Plant Sciences: Plant Analysis, Vol4, Pawan Kumar Scientific Publisher, India, ISBN: 81-7233-474-5.

Norziah, M.H. and C.Y. Ching 2000. Nutritional composition of edible seaweed Gracilaria changgi. Food Chem. 68:69-76.

Oohusa, T. 1993. Recent trends in nori products and market in Asia. Journal of Applied Phycology 5: 155-159.

Paine, R.T. and R.L. Vadas 1969. Calorific values of benthic marine algae and their postulated relationship to invertebrate food preference. Marine Biology 4:79-86.

Ruperez, P. 2002. Mineral content of edible marine seaweed. Food Chemistry 79: 23-26.

Subba Rao, P.V., V.A. Mantri and K. Ganesan 2007. Mineral composition of edible seaweed Porphyra vietnamensis. Food Chemistry 102: 215-218.

Vadas, R.L., B. Beal, T. Dowling and J.C. Fegley 2000. Experimental field tests of natural algal diets on gonad index and quality in the green sea urchin, Strongylocentrotus droebachiensis: a case for rapid summer production in post-spawned animals. Aquaculture 182: 115-135. 